J. Perinat. Med. 2 (1974) 176

\section{The influence of hypoxia on uterine and maternal placental blood flow, and the effect of $\alpha$-adrenergic blockade}

\section{K. Karlsson}

Department of Gynecology and Obstetrics I (Head: Professor S. Brody)

Department of Physiology (Head: Professor B. Folkow)

University of Göteborg, Sweden

Received January 28, 1974. Accepted March 27, 1974.
The peripheral blood flow in all species is widely redistributed during hypoxia. Dependent upon the species and the respiratory response a lowering of the arterial $\mathrm{P}_{\mathrm{O}_{2}}$ gives an increase in cardiac output and in heart frequency, or a decrease in the same parameters [11]. The general pattern of response is a reduction of blood flow to most organs, but preservation or even an increase of blood flow to vital organs - the brain and the myocardium. In pregnancy a special situation is established since the placenta is a non-vital organ for the mother but a vital organ for the fetus. The question arises, whether the uterusplacenta circuit will take part in the general peripheral vasoconstriction during maternal hypoxia, or whether the blood flow will be preserved.

Great difficulties have earlier been encountered when studying the uterine circulation. The position of the organ, with several vessels both on the inflow and outflow side, has complicated the study of circulation of this special organ. Information on the uterine circulation in pregnancy during hypoxia is conflicting. Thus Assalr et al. [2] found a progressive increase in blood flow to the uterus in pregnant ewes, when these were breathing 10 per cent oxygen, while Duncan et al. [5] found a reduction in the total uterine blood flow, probably because of local vasoconstriction during hypoxia. The latter authors performed their investigations on rabbits with the microsphere technique and found, apart from the reduction of uterine blood flow, a redistribution of the total flow within the organ, so that the fraction going to the placenta was reduced from about 60 to about 32 per cent during hypoxia.

In a study using the macroaggregate distribution technique Power et al. [15] found that the distribution in the placenta became more uniform, when the animal was hypoxic, giving a less variable local relation between the maternal and fetal flow. This indicates a placental vasodilatation.

The present experiments were performed to investigate whether hypoxic vasoconstriction takes place in the uterus-placental circulation in the pregnant rabbit, and if so, what the mechanism for vasoconstriction might be.

\section{Material and Methods}

The material consisted of 14 pregnant rabbits with dated gestations from 25 to 30 days. The pregnant term for rabbits is $31 \pm 2$ days. The mean body weight was $4.39 \mathrm{~kg} \pm 0.16$ (SD). Anesthesia was induced with pentothal $(25 \mathrm{mg} /$ $\mathrm{kg}$ ) through a catheter in a lateral ear-vein, and maintained with additional small amounts of pentothal. The rabbit was placed on a warm table and the trachea cannulated. The animal was artificially ventilated with known gas mixtures using a small animal Ideal Pump (volume/ frequency $=22 \mathrm{ml} / 36 \mathrm{rpm}$ ).

Arterial blood pressure and heart frequency were registered through a catheter in the right brachial artery. The signals were monitored by a STATHAM P 23 AC transducer, amplified and recorded on a Grass model 7 polygraph. Samples for blood gas determinations were taken through the same 
catheter. Blood gas measurements were made on a Radiometer pHM 27-gas monitor equipment, using a Clark-type $\mathrm{P}_{\mathrm{O}_{z}}$ electrode and a SeVeringHaus-type $\mathrm{P}_{\mathrm{CO}_{2}}$ electrode.

Radioactive microspheres (vide infra) were injected via a PE 160 catheter inserted with the tip in the left cardiac ventricle, the position being controlled by pressure measurement. The reference blood sample was withdrawn through a catheter in the left femoral artery at a constant rate $(2.93 \mathrm{ml} / \mathrm{min})$. The withdrawal was started 15 seconds before the injection of microspheres, and was continued for a total time of two minutes. The microspheres were injected over a period of 15-20 seconds. The injection chamber was carefully agitated before and during the injection using a high frequency mechanical whirlmixer, and afterwards the chamber was flushed with 6 to $12 \mathrm{ml}$ of 6 per cent Dextran, according to the volume withdrawn.

To check whether the time of sampling was long enough, the blood was collected in two portions, the second portion collected during the last 15 seconds. To check whether the microspheres became well mixed in the cardiac output during the left ventricular injection, blood was withdrawn simultaneously and at identical rates from one brachial as well as from one femoral artery, and the radioactivities of the two blood samples were compared (10 cases).

Periods of normoxia and hypoxia were alternated by ventilating the animals with gas mixtures of 30 per cent and 10 per cent oxygen. Thus, in 10 experiments the period of normoxia preceded the hypoxic period and in 4 experiments the reverse was true. Blood gas determinations demonstrated that a steady state situation was usually established when the animal had been ventilated with the desired gas mixture for ten minutes. At this stage the radioactive microspheres were injected.

Cardiac output was measured before, during and after the different stages of normoxia and hypoxia by means of a thermodilution method. At each stage the mean of 3-4 separate determinations was calculated. With the help of a calibrated jetsyringe one $\mathrm{ml}$ of saline (room temperature) was injected through the left ventricular catheter. The saline was injected manually in approximately 0.1 seconds. A fine calibre thermistor placed in the aorta recorded the variations of temperature. The thermistor was connected to a WHEATSTONE bridge to give a maximal linearity around 37 to $38^{\circ} \mathrm{C}$. The signal was recorded on a linear potentiometer writer (SERvogor). The calculations were performed according to GANZ [8].

In five additional experiments the effects of hypoxia on the uterine circulation was tested after blockade of the adrenergic $\alpha$-receptors with phenoxybenzamine (Dibenzyline ®), $10 \mathrm{mg} / \mathrm{kg}$. The drug was given slowly i. v. before both the normoxic and hypoxic blood flow determinations were performed.

At the end of the experiment the rabbit was killed with an overdose of pentothal. The heart was opened and the position of the catheter tip in the left ventricle was checked. Sample was taken from the lung to see the degree of existing $a-v$ shunts. The uterus, placenta, vagina, ovaries and kidneys were removed, dissected and weighed. The organs were cut in small pieces and packed in plastic tubes, $15 \times 150 \mathrm{~mm}$. Great care was taken to allow the organs to fill the bottoms of the tubes and not to let the tissue surface exceed two centimeters from the bottom.

\subsection{The microspheres}

Two types of radioactive carbonized microspheres were used, namely ${ }^{46}$ Scandium and ${ }^{169}$ Ytterbium, either $25 \pm 5$ (SD) or $35 \pm 5$ (SD) micron in diameter, with a density of 1.3 to 1.6 (MrNnesota Mining \& Manufacturing Co.). The spheres were delivered suspended in 20 per cent Dextran. The initial specific activity of the homogenous sphere suspension was $0.1 \mathrm{mCi} / \mathrm{ml}$. To obtain a homogeneous suspension a whirlmixer was used during the experiments. About $0.25 \mathrm{ml}$ of the nuclide suspension was injected. This corresponded to an amount in single spheres of around 100.000 with a diameter of 35 micron, and around 210.000 when the diameter was 25 micron. Radioactivity was measured with a lead-shielded well scintillation detector using a $2 \times 2$ inches thalliumactivated sodium iodide crystal. The output of the detector was connected to a gamma spectrometer (PACKARD auto-gamma spectrometer). 1000 volts were applied to the photo multiplier tube. 
Gamma spectra of ${ }^{46} \mathrm{Sc}$ and ${ }^{169} \mathrm{Yb}$ as well as of ${ }^{137} \mathrm{Cs}$ standard were made using a 2 per cent window setting.

${ }^{137} \mathrm{Cs}$ has a major peak at $662 \mathrm{kev},{ }^{46} \mathrm{Sc}$ has two peaks at 890 and $1120 \mathrm{kev}$, while ${ }^{169} \mathrm{Yb}$ has its major peaks at 177 and $198 \mathrm{kev}$. Finally the gain of each channel was adjusted in such a way that the major peaks of ${ }^{169} \mathrm{Yb}$ were counted in window $\mathrm{A}$, and those of ${ }^{46} \mathrm{Sc}$ in window $\mathrm{B}$. The energy was counted simultaneously in two channels. With the window settings used ${ }^{169} \mathrm{Yb}$ was counted only in window $\mathrm{A}$, while ${ }^{46} \mathrm{Sc}$ was counted in both windows. The ratio ( $r$ ) of ${ }^{46} \mathrm{Sc}$ activity seen in window $\mathrm{A}$ to that seen in window $\mathrm{B}$ was calculated at each measurement, and was found to be almost constant during each measurement period $(0.27-0.29)$.

The measured radioactivity was registrated on a punch-tape, which was used for automatic calculations on a table calculator, in which consideration was taken to the decay of the nuclides used [16]. To calculate the specific activity of each single microsphere (after background subtraction) the activity of known numbers of ${ }^{46} \mathrm{Sc}$ and ${ }^{169} \mathrm{Yb}$ was counted along with the tissue samples at each measurement. Based on these calculations, the number of spheres in each sample was determined. To decrease the error of blood flow determination due to random distribution of microspheres, no organ sample was accepted unless it contained at least 400 microspheres [3].

In the statistical analysis of the results the mean $(\bar{X})$, the standard deviation (SD) and the standard error of the mean (SEM) were calculated. Comparisons were carried out with the help of Group comparison Test.
Degrees of significance w're marked as follows: $*=0.05>\mathrm{P}>01 * *=0.01>\mathrm{P}>0.001$ $* * *=\mathrm{P}<0.001$.

\section{Results}

No specific effects of the anesthesia or the surgical procedure on the animals were observed [13].

Comparison between the radioactivity in the blood samples drawn simultaneously from the femoral and brachial artery demonstrated that the microspheres were well mixed in the blood. The ratio between the radioactivity in the femoral and brachial artery was $1.01 \pm 0.07(\mathrm{SD})$ for ${ }^{169} \mathrm{Yb}$, and $1.06 \pm 0.17$ (SD) for ${ }^{46} \mathrm{Sc}$.

The collected reference blood samples were divided in two parts, the last part consisting of blood drawn during the last 15 seconds. Activity was counted in both parts of the blood samples. Less than 1 per cent of the total activity counted of either ${ }^{169} \mathrm{Yb}$ or ${ }^{46} \mathrm{Sc}$ was found in the last 15 seconds portion. Thus, two minutes was an adequate period of time for sampling. To examine whether $\mathrm{a}-\mathrm{v}$ shunts large enough to allow the passage of 25 or 35 micron spheres existed in the rabbit, organ samples were taken from the lungs and the activity counted. It was then assumed, that the part of the lung examined was representative of the whole lung. Less than 0.24 per cent for ${ }^{169} \mathrm{Yb}$ and less than 0.21 per cent for ${ }^{46} \mathrm{Sc}$ of the total activity was found in the lungs. Tab. I presents data on cardiac output, heart frequency and mean arterial pressure in the animals during normoxia and hypoxia. The values were obtained after the animals had been breathing either 30 per cent or $10-15$ per cent oxygen for ten minutes.

Tab. I. Mean values \pm SEM of cardiac output, heart frequency and arterial pressure, without and with $\alpha$-adrenergic blockade.

\begin{tabular}{|c|c|c|c|c|c|c|c|}
\hline & & \multicolumn{2}{|c|}{$\begin{array}{l}\text { cardiac output } \\
\mathrm{n} \mathrm{ml} / \mathrm{min}\end{array}$} & \multicolumn{2}{|c|}{ heart frequency } & \multicolumn{2}{|c|}{$\begin{array}{l}\text { mean art. pressure } \\
\text { n . } \mathrm{mm} \mathrm{Hg}\end{array}$} \\
\hline - $\alpha$ blockade & $\begin{array}{l}\text { normoxia } \\
\text { hypoxia. } \\
\text { significance }\end{array}$ & $\begin{array}{l}14 \\
14\end{array}$ & $\begin{array}{l}698 \pm 25.5 \\
607 \pm 30.1 \\
*\end{array}$ & $\begin{array}{l}14 \\
14\end{array}$ & $\begin{array}{l}305 \pm 8.8 \\
266 \pm 10.0 \\
*\end{array}$ & $\begin{array}{l}14 \\
14\end{array}$ & $\begin{array}{l}81 \pm 1.7 \\
80 \pm 2.6 \\
\text { n.s. }\end{array}$ \\
\hline$+\alpha$ blockade & $\begin{array}{l}\text { normoxia } \\
\text { hypoxia } \\
\text { significance }\end{array}$ & $\begin{array}{l}5 \\
5\end{array}$ & $\begin{array}{l}560 \pm 30.2 \\
595 \pm 39.7 \\
\text { n.s. }\end{array}$ & $\begin{array}{l}5 \\
5\end{array}$ & $\begin{array}{l}339 \pm 9.0 \\
333 \pm 7.5 \\
\text { n.s. }\end{array}$ & $\begin{array}{l}5 \\
5\end{array}$ & $\begin{array}{c}43 \pm 1.6 \\
36 \pm 1.1 \\
*\end{array}$ \\
\hline
\end{tabular}


Tab. II. Mean arterial blood gases \pm SEM during normoxia and hypoxia without and with $\alpha$-adrenergic blockade.

\begin{tabular}{|c|c|c|c|c|c|c|c|}
\hline & & $\mathbf{n}$ & $\begin{array}{l}\mathrm{Po}_{2} \\
\mathrm{~mm} \mathrm{Hg}\end{array}$ & $\mathbf{n}$ & $\begin{array}{l}\mathrm{PCO}_{2} \\
\mathrm{~mm} \mathrm{Hg}\end{array}$ & $\mathrm{n}$ & $\mathrm{pH}$ \\
\hline$-\alpha$ blockade & $\begin{array}{l}\text { normoxia } \\
\text { hypoxia }\end{array}$ & $\begin{array}{l}14 \\
14\end{array}$ & $\begin{array}{l}91.8 \pm 3.4 \\
36.5 \pm 1.4\end{array}$ & $\begin{array}{l}14 \\
14\end{array}$ & $\begin{array}{l}37.6 \pm 1.6 \\
37.7 \pm 1.6\end{array}$ & $\begin{array}{l}14 \\
14\end{array}$ & $\begin{array}{l}7.35 \pm 0.02 \\
7.36 \pm 0.02\end{array}$ \\
\hline$+\alpha$ blockade & $\begin{array}{l}\text { normoxia } \\
\text { hypoxia }\end{array}$ & $\begin{array}{l}5 \\
5\end{array}$ & $\begin{array}{l}90.6 \pm 14.0 \\
43.8 \pm 2.8\end{array}$ & $\begin{array}{l}5 \\
5\end{array}$ & $\begin{array}{l}30.0 \pm 3.4 \\
29.6 \pm 2.4\end{array}$ & $\begin{array}{l}5 \\
5\end{array}$ & $\begin{array}{l}7.38 \pm 0.03 \\
7.32 \pm 0.03\end{array}$ \\
\hline
\end{tabular}
Tab. III. The vascular resistance $\left(\frac{\mathrm{mm} \mathrm{Hg}}{\mathrm{ml} /(\min \times 100 \mathrm{~g})}\right)$ of different organs during normoxia and hypoxia without and
with $\alpha$-adrenergic blockade.

\begin{tabular}{|c|c|c|c|c|c|c|c|c|c|c|c|}
\hline & & $\mathrm{n}$ & myometrium & $\mathrm{n}$ & placenta & $\mathrm{n}$ & vagina & $\mathrm{n}$ & ovaries & $\mathrm{n}$ & kidneys \\
\hline \multirow{3}{*}{$-\alpha$ blockade } & normoxia & 9 & 3.13 & 7 & 2.17 & 9 & 2.89 & 9 & 0.27 & 9 & 0.22 \\
\hline & hypoxia & 9 & 5.71 & 7 & 8.36 & 9 & 3.44 & 9 & 0.33 & 9 & 0.48 \\
\hline & significance & & $* *$ & & $* *$ & & n. s. & & n. s. & & $* *$ \\
\hline \multirow{3}{*}{$+\alpha$ blockade } & normoxia & 5 & 2.51 & 5 & 4.75 & 5 & 2.35 & 5 & 0.24 & 5 & 0.20 \\
\hline & hypoxia & 5 & 2.58 & 5 & 5.60 & 5 & 2.20 & 5 & 0.14 & 5 & 0.24 \\
\hline & significance & & n. s. & & n. s. & & n. s. & & n. s. & & n. s. \\
\hline
\end{tabular}

None of the animals showed any change of blood pressure during the injection of microspheres. Some of the rabbits had a slight depression of heart frequency, but it was restored in a few seconds.

The effect on blood gases can be seen in Tab. II. By ventilating the animals with air for normoxia, it proved difficult to keep $\mathrm{P}_{\mathrm{O}_{2}}$ at a normal level, probably because of atelectasis, so the animals were ventilated with 30 per cent oxygen.

The changes in blood flow to uterus, placenta, vagina, ovaries and kidneys when going from normoxia to hypoxia are graphically demonstrated in Fig. 1. Under normal conditions, without $\alpha$-blockade, there was a significant reduction in blood flow $(\mathrm{ml} /(\min \times 100 \mathrm{~g}))$. This decrease of blood flow is parallelled by an increased vascular resistance during hypoxia (Tab. III). When the $\alpha$-adrenergic receptors were blocked before the experiment, cardiac output and mean arterial blood pressure fell, while heart frequency increased, as compared to the nonblocked situation, Tab. I. When hypoxia was instituted no statistically significant changes of these variables occurred except in mean arterial pressure.

The blood flow to the various organs studied showed small variations during hypoxia in the $\alpha$-receptor blocked situation. Blood flow (ml/
BLOOD FLOW, $\mathrm{ml} /(\min =100 \mathrm{~g})$
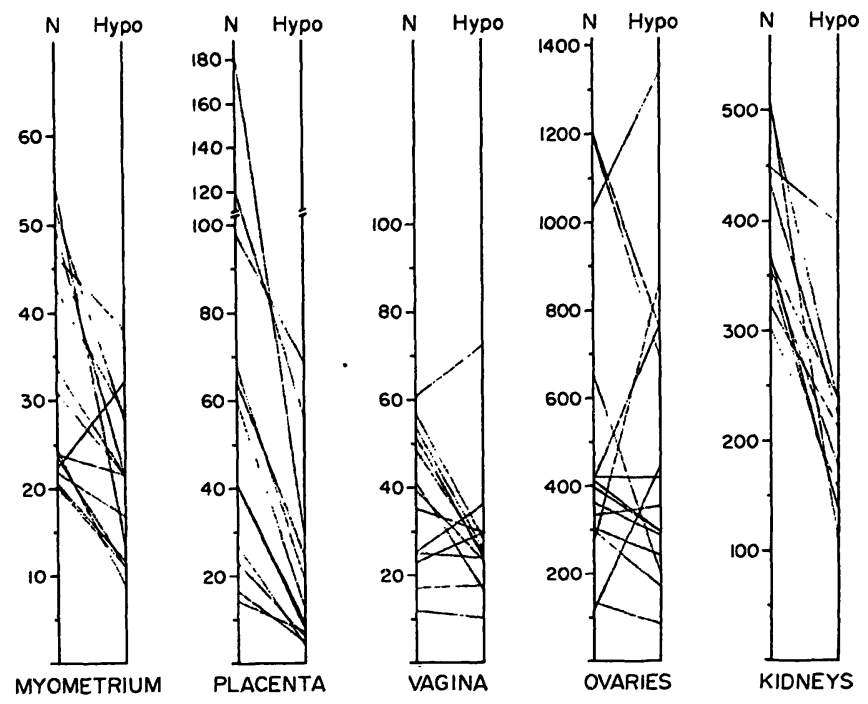

Fig. 1. Graphic demonstration of blood flow in different organs when changing from normoxia to hypoxia.

$\mathrm{N}=$ Normoxia, Hypo $=$ Hypoxia.

$(\min \times 100 \mathrm{~g}))$ to the kidneys decreased moderately, from 249 ( \pm 65.2$)$ to 165 ( \pm 44.0$)$ during hypoxia $(P<0.05)$, while neither the blood flow through the uterus, placenta, vagina or the ovaries demonstrated a statistically significant change. The lack of effect of hypoxia on vascular resistance after blockade is apparent from Tab. III. 
Tab. IV. Absolute blood flow $(\mathrm{ml} / \mathrm{min}) \pm \mathrm{SEM}$ to myometrium and placenta during normoxia and hypoxia, without and with $\alpha$-adrenergic blockade.

\begin{tabular}{|c|c|c|c|c|c|}
\hline & & $\mathrm{n}$ & myometrium & $\mathrm{n}$ & placenta \\
\hline & normoxia & 14 & $15.2 \pm 1.7$ & 12 & $24.3 \pm 7.0$ \\
\hline$-\alpha$ blockade & $\begin{array}{l}\text { hypoxia } \\
\text { significance }\end{array}$ & 14 & $\begin{array}{l}9.2 \pm 1.1 \\
* * *\end{array}$ & 12 & $\begin{array}{c}7.4 \pm 1.9 \\
* *\end{array}$ \\
\hline$+\alpha$ blockade & $\begin{array}{l}\text { normoxia } \\
\text { hypoxia } \\
\text { significance }\end{array}$ & $\begin{array}{l}5 \\
5\end{array}$ & $\begin{array}{c}10.5 \pm 1.6 \\
8.8 \pm 1.7 \\
\text { n.s. }\end{array}$ & $\begin{array}{l}5 \\
5\end{array}$ & $\begin{array}{c}3.5 \pm 1.3 \\
3.0 \pm 1.0 \\
\text { n. s. }\end{array}$ \\
\hline
\end{tabular}

The absolute blood flow to myometrium and placenta during normoxia and hypoxia with and without $\alpha$-blockade can be seen in Tab. IV. The fraction of the cardiac output going to the myometrium is 2.17 per cent during normoxia and 1.51 per cent during hypoxia, while that to placenta changes from 3.48 per cent to 1.21 per cent, when the animal is exposed to hypoxia. When the animals are pretreated with $\alpha$-blockade, the corresponding figures for uterus are 1.87 per cent and 1.48 per cent, while those for placenta change from 0.63 per cent to 0.50 per cent. To check whether the injection of microspheres earlier in the experiments had any influence on the flows later in the experiments, the flow values to myometrium, placenta and kidneys during normoxia at the first and the second flow determination were compared. No statistical difference in flow values was found, whether large amounts of ${ }^{169} \mathrm{Yb}$ or ${ }^{46} \mathrm{Sc}$ (200.000 spheres) were first injected. Neither was any tendency observed between the individual values.

\section{Discussion}

The cardiac output of the rabbit was found to be close to $700 \mathrm{ml} / \mathrm{min}$ or $148 \mathrm{ml} /(\mathrm{min} \times \mathrm{kg})$. The figures obtained are somewhat higher than those of Neutze et al. [13], who used dye-dilution curves and found a cardiac output of $110 \mathrm{ml} /$ $(\min \times \mathrm{kg})$. As known from human beings, the cardiac output increases during pregnancy [12]. The difference in values might depend on the different methods used, but might also depend on pregnancy in itself. The increase, in late pregnancy has been claimed to be about 30 to 40 per cent. The higher values in the present investigation might therefore be acceptable considering that Neutze et al. [13], and Edwards et al. [7], gave cardiac output values of non-pregnant rabbits. Duncas's values on cardiac output [6] are lower than in the present series. She used pregnant rabbits, in which cardiac output was calculated directly from the microspheres injected, a method which is critically dependent on the estimation of the total amount of radioactive microspheres injected. In the present investigation an independent thermodilution method was used. This method was recently validated against direct flow rates in experimental animals [10].

Angell James and De Burgh Daly [1] demonstrated that in animals with controlled ventilation hypoxia produces bradycardia and reduction of cardiac output through stimulation of the arterial chemoreceptors. The results of the present study corroborate these findings.

In this series of experiments hypoxia caused a consistant and significant fall in blood flow to the myometrium, and an even more pronounced fall in flow to the placenta (Fig. 1, Tab. IV). This is in contrast to the observations of an increased blood flow to the uterus of ewes obtained by the direct flow-metering method of Assali et al. [2]. The present results, however, are in accordance with the findings of Druts et al. [4], who used the electromagnetic flowmeter method on ewes to estimate the flow to uterus, but somewhat different from Duncan's results [6]. She found no diminution in myometrial flow, but a reduction in placental flow. The reason for this discrepancy is not apparent. It should be noted, however, that Duncan's report does not contain information about the number of spheres trapped in the myometrium - an item of information recently demonstrated to be of vital importance for the statistical error of determination [3]. 
Previous investigations by Greiss et al. [9] demonstrated a vasoconstrictor response in the uterine vascular bed during stimulation of sympathetic nerve fibres and OwMAN et al. [14] using a histochemical method were able to demonstrate adrenergic nerve fibres reaching both the myometrial smooth muscle cells and the blood vessels of the myometrium.

The present investigation with $\alpha$-blockade can be best explained by the existence of $\alpha$ adrenergic receptor sites in the vessels of the myometrium, and makes it probable that the vasoconstriction here during hypoxia is mediated by sympatho-adrenergic vasoconstric-

\section{Summary}

The vascular system generally reacts to a hypoxic stimulus with a reduction of blood flow, though in some vital organs, as for example the heart and the brain, an increase of blood flow is observed during hypoxia. In pregnancy a special situation is established, since the placenta is a non vital organ to the mother, but a vital organ to the fetus. Controversy exists in the literature whether a vasodilatation or a vasoconstriction takes place in the placenta and the myometrium during hypoxia.

Uterine circulation studies have been complicated to perform because of the complex arrangement of the vascular supply. As it is the placenta which is of interest in the exchange of products between the mother and the fetus, it is also the flow to this organ which is of special importance. After the introduction of the microspheres in the circulation studies, it has become possible to evaluate flow changes to and within previously inaccessible organs, as for instance the placenta. The present investigation was designed to study the effect of hypoxia on the vascular bed of the maternal part of the placenta and the myometrium and to elucidate the role of sympathoadrenal mechanisms in these reactions.

Utero-placental circulation studies were performed on 14 pregnant rabbits, with dated gestation (25-30 days). Anesthesia was induced and maintained with pentothal. The animals were artificially ventilated, and heart frequency and blood pressure were continuously recorded. The animals were alternatingly ventilated with 10 or 30 per cent oxygen. To avoid a systematic effect from a deterioration of the preparation the animals were ventilated in such a way that normoxia preceded hypoxia in ten animals, and in four animals the reverse was true. Blood gases were determined at intervals, cardiac output was determined repeatedly with a thermodilution method.

Radioactive microspheres of 25 or 35 micron diameter, tagged with either ${ }^{46} \mathrm{Sc}$ or ${ }^{169} \mathrm{Yb}$ were used to measure myometrial and placental blood flow during normoxia and hypoxia. After a steady state had been achieved (checked by blood gas determinations) with either normoxia or hypoxia, the microspheres were injected through a catheter tor mechanisms (Tabs. III-IV), but as no innervation has been dimonstrated in placenta, it seems probable, that the diminished flow is mediated via released circulating catecholamines.

In conclusion, the present experiments suggest that all the female reproductive organs, including the myometrium and the maternal part of the placenta, take part in a generalized peripheral vasoconstriction imposed by maternal hypoxia. The results further suggest that this vasoconstriction is mediated by liberated catecholamines acting on $\alpha$-adrenergic receptor sites both in the myometrium and the placenta.

placed in the left cardiac ventricle. Assuming that the microspheres are distributed in proportion to regional blood flow, blood flows were calculated from the number of spheres trapped in each organ related to the number of spheres in a reference sample, drawn from one femoral artery at a constant, known rate during and after the injection. The effect of $\alpha$-receptor blockade was tested by giving phenoxybenzamine $(10 \mathrm{mg} / \mathrm{kg})$ to the rabbit. The mixing of the microspheres in the blood after the ventricular injection was checked in ten animals by drawing simultaneously samples from the femoral and the brachial artery at equal rates. The results indicate a complete mixing. The $\mathrm{PO}_{2}$ changed from $92 \pm 3 \mathrm{~mm} \mathrm{Hg}$ during normoxia to $37 \pm 1 \mathrm{~mm} \mathrm{Hg}$ during hypoxia. No influence was observed in $\mathrm{PCO}_{2}$ or $\mathrm{pH}$ (Tab. II). A decrease in cardiac output and heart frequency was induced by hypoxia, no effect was seen on blood pressure (Tab. I).

A significant decrease in myometrial blood flow was seen from $15.2 \pm 1.7 \mathrm{ml} / \mathrm{min}$ to $9.2 \pm 1.1 \mathrm{ml} / \mathrm{min}$ parallelled by an increase in vascular resistance from 3.13 to 5.71 when changing from normoxia to hypoxia (Tabs. III-IV, Fig. 1). A still more pronounced decrease was observed in the placental blood flow from $24.3 \pm 7.0 \mathrm{ml} / \mathrm{min}$ to $7.4 \pm 1.9 \mathrm{ml} / \mathrm{min}$, here too parallelled by an increase in vascular resistance from 2.17 to 8.36 .

Blockade of the $\alpha$-receptors induced a reduction of mean arterial pressure from $81 \mathrm{~mm} \mathrm{Hg}$ to $43 \mathrm{~mm} \mathrm{Hg}$ together with a decrease of the cardiac output from 698 to $560 \mathrm{ml} / \mathrm{min}$ (Tab. I). Since hypoxia induced a reduction of the mean arterial pressure during $\alpha$-blockade, it seemed more meaningful to study the change in vascular resistance instead of the changes in blood flow during these circumstances. During $\alpha$-blockade the vascular resistance to the myometrium was 2.51 and 2.58 respectively when changing from normoxia to hypoxia. Correspondingly the vascular resistance to the placenta changed non-significantly from 4.75 to 5.60 in the same situations.

The effectiveness of the amount of phenoxybenzamine given to block the $\alpha$-receptors, was verified by observing that no change in vascular resistance to the kidneys was 
introduced when changing from normoxia to hypoxia during $\alpha$-blockade (vascular resistance 0.20 to 0.24 respectively).

Thus, a clear lack of hypoxic effect on the myometrium and the placenta was demonstrated, when $\alpha$-blockade was added.
The present investigation demonstrated that a reduction in placental blood flow to one third of its initial value was induced during hypoxia. Furthermore it was demonstrated, that the effect of hypoxia on the placental and myometrial blood flow was mediated via liberated catecholamines.

Keywords: $\alpha$-adrenergic blockade, blood flow (myometrial, placental) hypoxia, normoxia, rabbits.

\section{Zusammenfassung}

Untersuchungen über den Einfluß einer Hypoxie auf die uterine und plazentare Durchblutung sowie die Wirkung von Beta-Adrenergika

Das Gefäß-System beantwortet einen hypoxischen Reiz generell mit einer Reduktion der Durchblutung. In manchen lebenswichtigen Organen jedoch, wie z.B. dem Herzmuskel und dem Gehirn, beobachtet man eine $\mathrm{Zu}-$ nahme der Durchströmung während der Hypoxie. Während der Schwangerschaft besteht eine besondere Situation insofern, als die Plazenta für den Feten ein lebenswichtiges Organ darstellt, nicht jedoch für die Mutter. Die Frage, ob während einer Hypoxie eine plazentare und myometriale Vasodilatation oder Vasokonstriktion einsetzt, wird in der Literatur unterschiedlich beantwortet. Die Untersuchungen über die uterine Zirkulation waren auf Grund der unübersichtlichen Gefäßversorgung erschwert. So wie die Plazenta im Hinblick auf den Austausch von Substanzen zwischen Mutter und Feten von Interesse ist, so ist auch die Durchblutung dieses Organes von ganz besonderer Bedeutung. Nach Einführung der MikroperlenTechnik in Durchblutungs-Studien gelang es, Durchströmungs-Änderungen auch jener Organe zu messen, die noch wenig zuvor als unerreichbar galten, wie z.B. die Plazenta.

In der vorliegenden Untersuchung sollte die Wirkung der Hypoxie auf das Gefäßbett der mütterlichen Seite der Plazenta und des Myometriums studiert und die Rolle der sympato-adrenalen Mechanismen bei diesen Reaktionen beleuchtet werden.

Die utero-plazentaren Durchblutungs-Studien wurden an 14 schwangeren Kaninchen im Gestationsalter von 25 bis 30 Tagen durchgeführt. Die Narkose wurde mit Penthotal eingeleitet und aufrechterhalten. Die Tiere wurden künstlich beatmet, und Herzfrequenz sowie Blutdruck kontinuierlich aufgezeichnet.

Die Tiere wurden im Wechsel mit 10 bzw. 30\% Sauerstoff beatmet. Um eine systematische, negative, durch die Versuchsanordnung bedingte Wirkung zu vermeiden, wurden 10 Tiere so beatmet, daß die Normoxie der hypoxischen Phase vorausging, während bei vier Versuchstieren das Gegenteil der Fall war. Die Blutgase wurden intermittierend, das Herzschlag-Volumen wiederholt mit Hilfe der Thermodilutionsmethode gemessen.

Für die Messung der myometrialen und plazentaren Durchblutung während der normoxischen und hypoxischen Phasen wurden radio-aktive Mikroperlen (25 oder 35 Micron $\varnothing$ ), die entweder mit ${ }^{46} \mathrm{Sc}$ oder ${ }^{169} \mathrm{Yb}$ markiert waren, verwendet. Nachdem sich ein Gleichgewicht sowohl bei Normoxie wie Hypoxie eingestellt hatte (kontrolliert durch Blutgas-Analysen), wurden die Mikroperlen durch einen im linken Herzen liegenden Katheter injiziert. In der Annahme, daß die Mikroperlen entsprechend den regionalen Durchblutungsgrößen verteilt werden, wurde die Durchblutung berechnet aus dem Verhältnis der Anzahl an Perlen, die in jedem Organ festgestellt wurden und der Anzahl an Perlen in einer Vergleichsprobe; diese Probe wurde aus einer Arteria femoralis in konstanten und bekannten Zeitabständen während und nach der Injektion entnommen. Die Wirkung einer Alpha-Rezeptor-Blockade wurde durch Applikation von Phenoxybenzamin $(10 \mathrm{mg} / \mathrm{kg})$ an den Kaninchen geprüft. Die Durchmischung der Mikroperlen im Blut nach der ventrikulären Injektion wurde bei 10 Tieren dadurch geprüft, daß gleichzeitig Blutproben aus Arteria femoralis und Arteria brachialis in gleichen Zeitabständen entnommen wurden. Die Resultate wiesen auf eine vollständige Dưrchmischüng hin.

Das $\mathrm{P}_{2}$ fiel von $92 \pm 3 \mathrm{~mm} \mathrm{Hg}$ während Normoxie auf $37 \pm 1 \mathrm{~mm} H \mathrm{Hg}$ während der Hypoxie-Periode. $\mathrm{PCO}_{3}$ und $\mathrm{pH}$ blieben unbeeinflußt (Tab. II). Die Hypoxie führt zu einem Rückgang des Herzschlag-Volumens und der Herzschlag-Frequenz, nicht jedoch zu einem Absinken des Blutdrucks (Tab. I).

Beim Wechsel von Normoxie auf Hypoxie zeigte sich eine signifikante Abnahme der myometrialen Durchblutung von $15,2 \pm 1,7 \mathrm{ml} / \mathrm{min}$. auf $9,2 \pm 1,1 \mathrm{ml} / \mathrm{min}$., der eine Zunahme des Gefäß-Widerstandes von 3,13 auf 5,71 entsprach (Tab. III-IV, Fig. 1). Eine noch stärkere Abnahme konnte beobachtet werden bei der plazentaren Durchblutung, die von $24,3 \pm 7,0 \mathrm{ml}$ min. auf $7,4 \pm 1,9 \mathrm{ml} / \mathrm{min}$. absank und ebenfalls von einer Zunahme des Gefäß-Wịderstandes von 2,17 auf 8,36 begleitet war.

Die Blockierung der Alpha-Rezeptoren führte zu einer Reduktion des mittleren arteriellen Blutdrucks von $81 \mathrm{~mm} \mathrm{Hg}$ auf $43 \mathrm{~mm} \mathrm{Hg}$ verbunden mit einer Abnahme des Herzschlag-Volumens von 698 auf $560 \mathrm{ml} / \mathrm{min}$. (Tab. I). Da die Hypoxie unter Alpha-Blockade zu einem Abfall des mittleren arteriellen Blutdrucks führt, schien es von größerer Bedeutung zu sein, unter diesen Bedingungen Veränderungen des Gefäß-Widerstandes anstatt Veränderungen der Durchströmung zu untersuchen. Der Wechsel von Normoxie auf Hypoxie unter AlphaBlockade führte zu einer Änderung des Gefäß-Widerstandes des Myometriums von 2,51 auf 2,58. Analog dazu veränderte sich in derselben Situation der GefäßWiderstand der Plazenta nicht signifikant von 4,75 auf 5,60. Die Wirksamkeit der Phenoxybenzamin-Dosis, die zur Blockade der Alpha-Rezeptoren verabfolgt worden war, 
wurde durch die Beobachtung verifiziert, $\mathrm{da} ß$ während des Wechsels von Normoxie auf Hypoxie unter Alpha-Blockade keinc Veränderungen des Gefäß-Widerstandes der Nieren erfolgtc (Gefäß-Widerstand 0,20 bzw. 0,24).

Es konnte also gezeigt werden, daß eine zusätzliche Alpha-Blockade den Hypoxie-Effekt auf das Myometrium und die Plazenta eindeutig verhindert.
Die vorliegende Untersuchung zeigt, daß eine HypoxiePeriode einen Rückgang der plazentaren Durchblutung auf ein Drittel des Ausgangswertes verursacht. Es wurde weiterhin gezeigt, daß der Hypoxie-Effekt auf cie plazentare und myometriale Durchblutung auf die Freisetzung von Katecholaminen zurückzuführen ist.

Schlüsselwörter: Alpha-adrenergische Blockade, Durchblutung (myometrial, plazentar), Hypoxie, Kaninchen, Normoxie.

\section{Résumé}

A propos de l'influence de l'hypoxie et de l'action des $\alpha$ bloquants sur le débit utérin et placentaire

Habituellement, l'appareil circulatoire réagit à l'hypoxie par une diminution du débit sanguin. Au niveau de certains organes vitaux, tels le ceour et le cerveau, on observe cependant une augmentation du flux circulatoire en cas d'hypoxie. La grossesse constitue un cas particulier, étant donné que si le placenta n'est pas un organe vital pour la mère, il est indispensable à la vie du foetus. Il existe une controverse parmi les auteurs, en ce qui concerne le comportement des vaissaux utéro-placentaires en cas d'hypoxie. Celle-ci engendre-t-elle une vasoconstriction ou une vasodilatation?

L'étude de l'hémodynamique utérine est très difficile à réaliser étant donné la complexité du système vasculaire à ce niveau. Si le placenta est très important pour la réalisation des échanges entre la mère et le foetus, le débit circulatoire de celui-ci l'est également. Depuis l'utilisation de la technique des microsphères en hémodynamique, il est devenu possible d'évaluer les variations de débit au sang d'organes autrefois inaccessibles, tel que le placenta. Ce travail a pour but l'étude de l'influence de l'hypoxie sur le lit vasculaire du placenta et du myomètre, et du rôle joué par les récepteurs adrénergiques au cours des modifications observées.

L'étude de l'hémodynamique utérine fut réalisée chez 14 lapines entre 25 et 30 jours de gestation, sous anesthésie au pentothal, ventilation artificielle, et contrôle permanent de la fréquence cardiaque et de la pression sanguine. Les animaux reçurent alternativement des mélanges à 10 et $30 \%$ d'oxygène. Afin d'éviter un effet systématique dû à la détérioration des préparations, les animaux furent ventilés de telle sorte qu'une période d'oxygénation normale précède l'hypoxie chez 10 animaux; chez les 4 autres, on fit l'inverse. On détermina régulièrement les valeurs des gaz du sang, et le débit cardiaque fut mesuré de façon répétée par thermodilution.

Des microsphères de 25 et 35 microns de diamètre, marquées au ${ }^{46} \mathrm{SC}$ et à ${ }^{1199} \mathrm{Yb}$ furent utiliséés pour déterminer les débits placentaire et utérin au cours de l'oxygénation normale et de l'hypoxie. Après l'établissement d'un état d'équilibre (mis en évidence par la mesure des gaz du sang) sous oxygénation normale et sous hypoxie, on injecta les microsphères dans la cavité cardiaque gauche à l'aide d'un cathéter. En postulant que les microsphères se distribuent dans la circulation sanguine proportionellement au débit sanguin dans chaque organe, les débits sanguins furent mesurés en calculant le nombre de sphères contenues dans chaque organe par rapport au nombre de sphères contenues dans un échantillon de référence, prélevé au niveau d'une artère fémorale et présentant un taux de radioactivité connu et constant pendant et près l'injection. On étudia l'effet du blocage des récepteurs $\alpha$ en administrant $10 \mathrm{mg} / \mathrm{Kg}$ de phénoxybenzamine à la lapine. On détermina l'homogénéité du mélange des sphères dans la circulation en prélevant simultanément des échantillons de radioactivité égaux dans les artères humérale et fémorale. Les résultats obtenus mirent en évidence l'homogénéité $d u$ mélange.

$\mathrm{La}_{\mathrm{a}} \mathrm{P}_{2}$ passa de $92 \pm 3 \mathrm{~mm} \mathrm{Hg}$ pendant l'oxygénation normale à $37 \pm 1 \mathrm{~mm} \mathrm{Hg}$ pendant l'hypoxie. On n'observa aucune différence de $\mathrm{PCO}_{\mathrm{C}}$ ni de $\mathrm{pH}$ (Tab. II). L'hypoxie provoqua une diminution du débit et du rythme cardiaques, mais pas de modification de la pression sanguine (Tab. I).

Lors du passage de l'état d'oxygénation normale à l'hypoxie, on observa une chute significative du débit myométrial de $15,2 \pm 1,7 \mathrm{ml} / \mathrm{min}$ à $9,2 \pm 1,1 \mathrm{ml} / \mathrm{min}$, et une augmentation de la résistance vasculaire de 3,13 à 5,71 (Tab. III-IV, Fig. 1). La chute de débit la plus importante concernait le débit placentaire qui passa de $24,3 \pm 7 \mathrm{ml} / \mathrm{min}$ à $7,4 \pm 1,9 \mathrm{ml} / \mathrm{min}$. Egalement dans ce cas, on observa une augmentation de la résistence vasculaire de 2,17 à 8,36 .

L'inhibition des récepteurs $\alpha$ produisit une réduction de la pression artérielle moyenne de $81 \mathrm{~mm} \mathrm{Hg}$ à $43 \mathrm{~mm} \mathrm{Hg}$, associée à une chute du débit cardiaque de 698 à $560 \mathrm{ml} / \mathrm{min}$ (Tab. I). Etant donné que l'hypoxie provoque une diminution de la pression artérielle moyenne lorsqu'elle est associée à un blocage des récepteurs $\alpha$, il a semblé plus logique d'étudier les modifications de la résistance vasculaire, plutôt que les variations de débit dans ces mêmes circonstances.

Lors de l'inhibition des récepteurs $\alpha$, la résistance vasculaire à travers le myomètre fut de 2,51 et de 2,58 en cas de normoxie et d'hypoxie. De même, la résistance vasculaire à travers le placenta ne se modifia pas de façon significative. Elle fut respectivement de 4,75 et de 5,60 dans les conditions identiques.

L'efficacité de la dose de phenoxybenzamine nécessaire pour inhiber les récepteurs $\alpha$, fut vérifiée par l'absence de modifications de la résistance vasculaire rénal au cours du passage de la normoxie à l'hypoxie (les valeurs furent respectivement de 0,20 et de 0,24$)$.

En conclusion, ceci nous a permis de mettrc en évidence la suppression des effets de l'hypoxie sur le myomètre 
et le placenta, lorsqu'on y associe un blocage des récepteurs $\alpha$.

Ce travail de recherche nous a aussi permis de mettre en évidence une chute de débit placentaire jusqu'à $1 / 3$ de sa valeur initiale au cours de l'hyṕoxie. Bien plus, nous avons démontré que cet effet de l'hypoxie sur les débits utérin et placentaire, était dû à une libération de catécholamines.

Mots-clés: Débit sanguin (myométriél, placentaire), hypoxie, inhibition des récepteurs $\alpha$-adrénergiques, lapines; normoxie.

\section{Acknowledgement}

This study was supported by Prenatalforskningsfonden, Swedish National Research Council Grant No. $19 X-2591$ and by a grant from Hässle Ltd.

\section{Bibliography}

[1] Angell James, J. E., M. de Burgh Daly: Cardiovascular responses in apnoic asphyxia: Role of arterial chemoreceptors and the modification of their effects by a pulmonary vagal inflation reflex. J. Physiol. (Lond.) 201 (1969) 87

[2] Assali, N. S., L. W. Holm, N. Sehgal: Hemodynamic changes in fetal lamb in utero in response to asphyxia, hypoxia and hypercapnia. Circulat. Res. 11 (1962) 423

[3] Buckberg, G. D., J. C. Luck, D. B. Payne, J. I. E. Hoffman, J. P. Archie, D. E. Fixler: Some sources of error in measuring regional blood flow with radioactive microspheres. J. Appl. Physiol. 31 (1971) 598

[4] Dilts, P. V., C. R. Brinkman, T. H. Kirschbaum, N. S. Assali: Uterine and systemic hemodynamic interrelationships and their response to hypoxia. Amer. J. Obstet. Gynec. 103 (1969) 138

[5] Duncan, S. B., B. V. Lewis: Maternal placental and myometrial blood flow in pregnant rabbits. J. Physiol. (Lond.) 202 (1969) 471

[6] Duncan, S. B.: The partition of uterine blood flow in the pregnant rabbit. J. Physiol. (Lond.) 204 (1969) 421

[7] Edwards, A. W. T., P. I. Korner, G. D. Thorburn: The cardiac output of the unanesthetized rabbit, and the effects of preliminary anesthesia, environmental

- temperature and carotid-occlusion. Quart. J. Exp. Physiol. 44 (1959) 309

[8] Ganz, W., R. Donoso, H. S. Marcus, J. S. Forrester, H. J. C. Swan: A new technique for measurement of cardiac output by thermodilution in man. Amer. J. Cardiol. 27 (1971) 392
[9] Greiss, F. C., F. L. Gobble: Effect of sympathetic nerve stimulation on the uterine vascular bed. Amer. J. Obstet. Gynec. 97 (1967) 962

[10] Hedvalu, G., I. KJellmer, T. Olsson: An experimental evaluation of the thermodilution method for determination of cardiac output and of intracardiac right-to-left shunts. Scand. J. clin. Lab. Invest. 31 (1973) 61

[11] Korner, P. I.: Control of the systemic circulation in hypoxia. Excerpta Med. 87 (1965) 137

[12] Lees, M. M., S. H. TAYLOR, D. B. Scott, M. G. KerR: A study of cardiac output at rest throughout pregnancy. J. Obstet. Gynaec. Brit. Cwlth. 74 (1967)319

[13] Neutze, J. M., F. Wyler, A. M. Rudolph: Use of radioactive microspheres to assess distribution of cardiac output in rabbits. Amer. J. Physiol. 215 (1968) 486

[14] Owman, Ch., E. Rosengren, N.-O. SJöberg: Adrenergic innervation of the human female reproductive organs: A histochemical and chemical investigation. Obstet. and Gynecol. 30 (1967) 763

[15] Power, G. G., L. D. Longo, H. N. Wagner, D. E. KUHL, R. E. FORSTER: Uneven distribution of maternal and fetal placental blood flow, as demonstrated using macroaggregates, and its repsonse to hypoxia. J. Clin. Invest. 46 (1967) 2053

[16] Rudolph, A. M., M. A. Heymann: The circulation of the fetus in utero. Methods for studying distribution of blood flow, cardiac output and organ blood flow. Circulat. Res. 21 (1967) 163 